\title{
窓を開放したときの隣戸への伝搬音の主観評価に関する実験的検討 \\ EXPERIMENTAL STUDY ON SUBJECTIVE EVALUATION OF TRANSMITTED SPEECH SOUND FROM OPEN WINDOWS
}

\author{
宮尾 健 一*1, 大川 平一郎*2, 山㟝芳 男*3, 子安 勝*4 \\ Ken-ichi MIYAO, Heiichiro OHKAWA, Yoshio YAMASAKI \\ and Masaru KOYASU
}

This study investigates subjective evaluation of transmitted speech sound from open windows. When windows are opened, sound pressure level difference decreases, but background noise increases in sound receiving room.

This paper describes the results of an experiment under conditions of open windows.

The results of this paper are as follows.

1. When windows are opened, background noise increases in sound receiving room, yet point of subjective evaluation for sound insulation decreases .

2. The relation of word intelligibility to level difference between transmitted speech sound and background noise level shows a defferent tendency in comparison with conditions of closed windows.

\section{Keywords: sound insulation,flanking transmission, transmitted speech sound level,}

background noise level, word detection, word intelligibility

遮音、側路伝搬、透過音レベル、背景音レベル、単語検知、単語了解度

\section{1.はじめに}

筆者らは、集合住宅における隣接住戸からの話し声が聞こえる といった事象の評価について、前報りでは、実験室における基礎 データを基にして、空が閉まり、側路伝搬のない状態を仮定した 物理量と主観評価量の関係を検討し、物理量としての透過音レベ ルと背景音レベルとの差の值が主観評価量と強い相関を示すこと を報告した。

しかし、実際の生活では、冷・暖房を必要としない中間期や、室 内に涼風を取入れたいときなどは、空を開放して生活することも 多く、隣接住戸からの話し声、テレビ、ステレオの音などの影響 が大きくなる。また、空の開放は、一般に背景音レベルを大きく し、この影響によっても聞こえ方は異なるものと考える。

この日常生活でしばしば起り得る問題に対応するために、本報 では、異なる空開放条件での空開放時の室間の遮音性能と主観評 価量との関係について明らかにすることを試みた。

主観評価のための建築的な基礎資料として、実際の集合住宅に おいて測定をした空開放・空閉鎖時の 2 室間の遮音性能を用いた 主観評価実験は、音源室・受音室の空の開閉条件および、受音室
の空開閉条件別に背景音レベルを変化させて、前報と同様の方法 により実施した。

\section{2. 基礎資料を得るための実建物での測定 ${ }^{2) （ 3)}$ \\ 2.1 測定方法}

測定対象室・測定経路は、図 1 に示したように、7 階建てR C 造集合住宅の 5 階の L D $\rightarrow$ 和室（以下 L D 系）、洋室 A $\rightarrow$ 洋室 B （以下洋室系）とした。測定室の諸元・仕様は、表 1 に示したよう に現在多く見られるものである。

空の開閉は、音源室・受音室の空共に対象隣接戸側のサッシの 戸（障子）を対象にすることにし、音源・受音室の空共に閉鎖（以 下「閉 $\rightarrow$ 閉」)、音源室の空のみ開放 (以下「開 $\rightarrow$ 閉」)、音源室·受

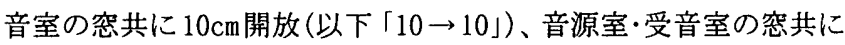
開放（以下「開 $\rightarrow$ 開」）の 4 通りとした。ここで、 $10 \mathrm{~cm}$ 開放の条件 は、風が強く少し空を開けるとき、少し外気を室内に入れたいと きを想定している。

これらの各条件について、主観評価実験の際の基礎資料として の室間音圧レベル差、残響時間を測定した。

\footnotetext{
*1 戸田建設侏技術研究所

*2 侏音環境研究所 所長・工博

Technical Research Institute, Toda Corp.
Sound Environment Research Inc., Dr. Eng.

*3 千葉工業大学情報工学科教授・工博

Department of Computer Science, Chiba Institute of Technology, Dr. Eng.

$* 4$ 住環境工房 理博

Building Environment Factory, Dr. Sci.
} 
特に、空開放時の室間音圧レベル差の測定については、JIS法の 室内の音圧分布に大きな差が生じ、適用ができないとも考えられ たので、まずJIS法によっても問題がないかどうかの検討をしたう えで測定をした。

\section{2 測定結果}

\section{2.1 JIS 法による㝕開閉条件別室間音圧レベル差測定 方法の検討}

集合住宅における室間音圧レベル差の測定では、通常、窓閉鎖 時を対象としているために、室内は拡散音場に近く測定点間の音 圧レベルのバラツキは小さいものと仮定し、測定点の数を 5 点と している（JIS A 1417 改定案では、移動マイクロホン法も含ま れている)。

しかし、空開放時では、室内が拡散音場とは大きく離れた状態 になり、測定点の数や室内平均音圧レベルの算出に問題を生じる おそれがある。すなわち、空開放時の測定では、室内音圧レベル のバラツキが大きくなり、測定值に影響を与えることも考えられ る。そこで、その影響の有無を確認するために、音源・受音室共、 約 $50 \mathrm{~cm}$ のメッシュを基本とした格子上の交点に測定点（以下「格 子点」）をとった場合と（ただし、音源室ではスピーカー近傍は除 いた)、JISに準拠した 5 点としたとき、それぞれについて、室間 音圧レベル差を測定した。

室間音圧レベル差の算出は、エネルギ平均値、算術平均値の両 者で求めた、その結果を測定点、空開閉条件の各条件ごとに図 2 に 示した。

この図によれば、

(1) 音源・受音室の空共に「閉 $\rightarrow$ 閉」のとき、両対象室共に算出方 法による差異は $1 \mathrm{~dB}$ 以内であった。

(2)「開 $\rightarrow$ 閉」のとき、格子点エネルギ平均値との差異が $2 \mathrm{~dB}$ を示 したのは、LD系において、125Hz帯域での 5 点算術平均值、 $2 \mathrm{kHz}$ 带域での 5 点エネルギ平均值、 5 点算術平均值であり、他は $1 \mathrm{~dB}$ 以内であった。

(3)「10 $\rightarrow 10 」$ のとき、格子点エネルギ平均値との差異は、L D系

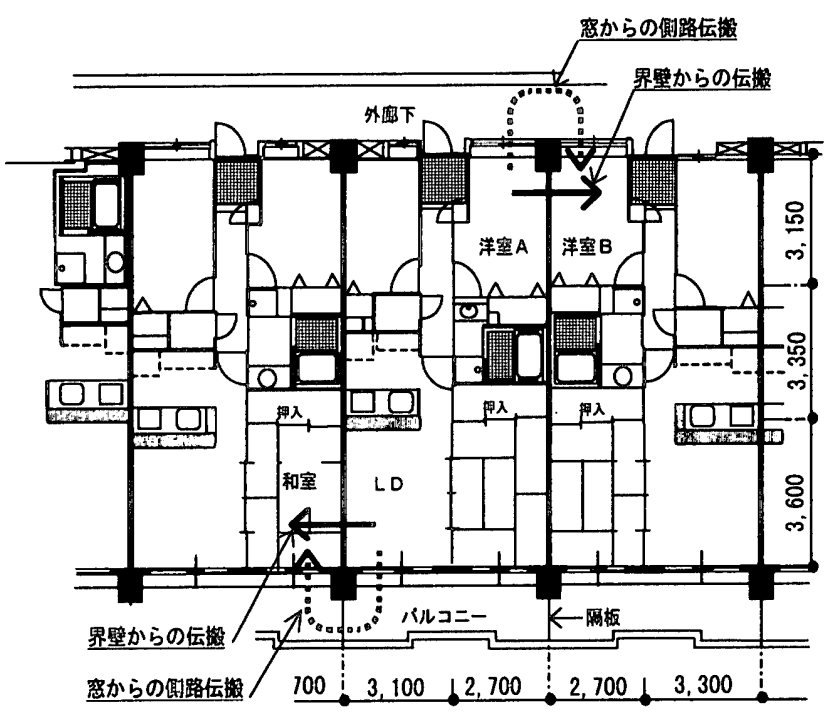

图 1 測定室・測定経路
表 1 測定室の諸元・仕様

\begin{tabular}{|c|c|c|c|c|c|c|}
\hline 测定窒 & $v$ & $s$ & 界壁 & 密 & $\begin{array}{l}\text { 量・天井 } \\
\text { 出上 }\end{array}$ & 床壮上 \\
\hline LD & 27.2 & 55.1 & \multirow[t]{4}{*}{$\begin{array}{l}\text { 苗通コンク } \\
\text { リートロ } \\
150 \mathrm{~mm} \\
\text { [各室共通] }\end{array}$} & \multirow{2}{*}{ 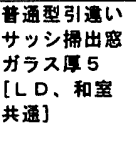 } & \multirow[t]{4}{*}{$\begin{array}{l}\text { ヒニニール } \\
\text { クロス張 } \\
\text { [各室共通] }\end{array}$} & $\begin{array}{l}\text { 防振ゴム } \\
\text { 贯床下地 } \\
\text { フローリン } \\
\text { グロ } 14\end{array}$ \\
\hline 和蜜 & 23.8 & 50.5 & & & & $\begin{array}{l}\text { 同上下地 } \\
\text { 化学量䨐 } 55\end{array}$ \\
\hline 洋窒 A & 18.7 & 43. 0 & & \multirow{2}{*}{ 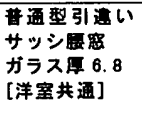 } & & \multirow{2}{*}{$\begin{array}{l}\text { 同上下地 } \\
\text { カーペット } \\
\text { 苂 } \\
\text { (フェルト } \\
\text { 19下地) }\end{array}$} \\
\hline 洋室 B & 17.1 & 40.2 & & & & \\
\hline
\end{tabular}

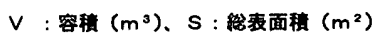

和空：解随子あり、LD・洋室A・洋窒B：カーテンなし

\begin{tabular}{|c|c|c|c|c|}
\hline 平均值策出方法 & 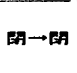 & 的十月 & $10 \rightarrow 10$ & $B \rightarrow B$ \\
\hline 格子点エネルキ平均任 & $=0$ & 0 & 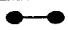 & $=-a$ \\
\hline 5慮エネルキ平均俩 & $\square$ & $0-0$ & 00 & 口. - \\
\hline 格子点面街平均任 & $\bullet$ & $\sim \cdots$ & $\leftrightarrow$ & $\leftrightarrow$ \\
\hline 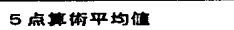 & $\infty$ & $\Delta--\Delta$ & $\Delta \Delta$ & $\infty-\infty$ \\
\hline
\end{tabular}
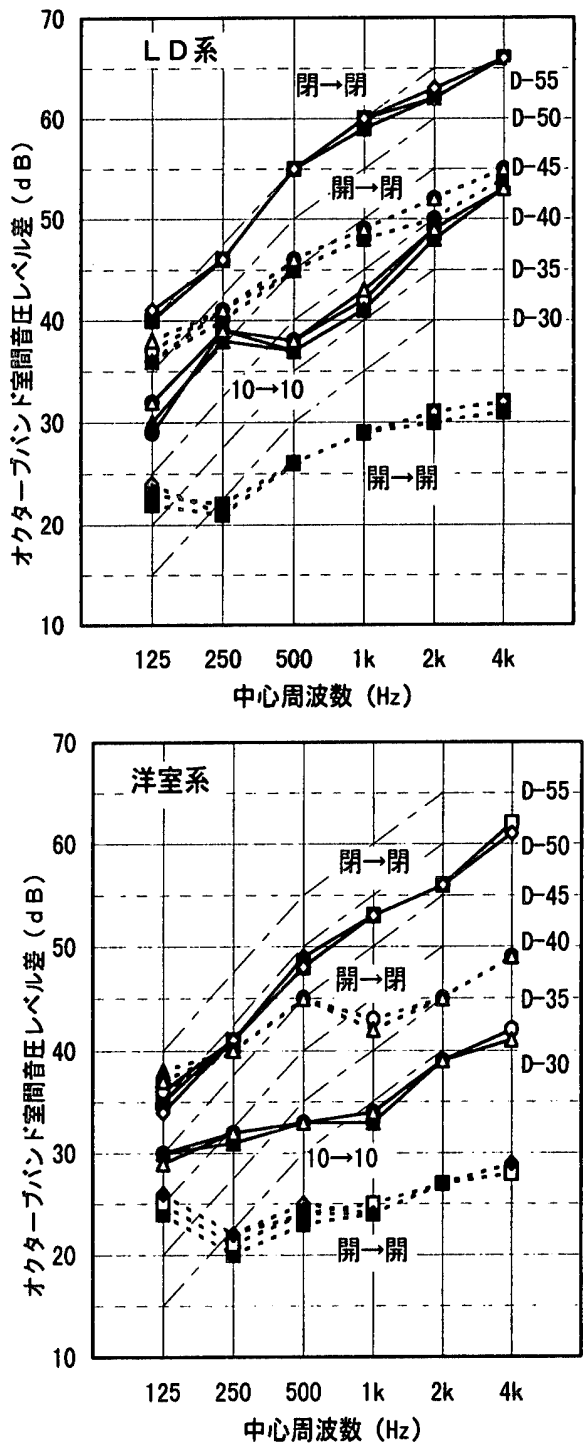

図 2 空開閉条件別室間音圧レベル差 
において、 $125 \mathrm{~Hz}$ 帯域での 5 点エネルギ平均値、 5 点算術平均値が $3 \mathrm{~dB} 、 2 \mathrm{kHz}$ 帯域での 5 点算術平均值が $2 \mathrm{~dB}$ であり、他は $1 \mathrm{~dB}$ 以 内であった。

(4)「開 $\rightarrow$ 開」のとき、格子点エネルギ平均値との差異が $2 \mathrm{~dB}$ を示 したのは、L D系における $125 \mathrm{~Hz}$ 帯域での 5 点算術平均值、洋室系 における $125 \mathrm{~Hz}$ 帯域・ $250 \mathrm{~Hz}$ 帯域での格子点算術平均値、5 点算 術平均佔、 $500 \mathrm{~Hz}$ 帯域での 5 点算術平均値であり、他は $1 \mathrm{~dB}$ 以内 であった。

以上のことから、基本的には、空開放時の測定においても、JIS 法を適用しての測定でよいと判断した。

\subsection{2 基礎資料としての室間音圧レベル差}

空開放時でも、JIS法の適用による測定点 5 点での測定でよいこ とを示したが、一部の条件を除き、格子点エネルギ平均值と 5 点 エネルギ平均值がほぼ同じ值を示していることから、測定点 5 点 での測定値のエネルギ平均値による值を用いることにした。

得られた空開閉条件別に、室間音圧レベル差は D数 $(1 \mathrm{~dB}$ ステッ ク゚で読みとり) で表示し表 2 に示した。

表 2 から次のことがいえる。

(1) $\mathrm{D}$ 数は、音源室・受音室の空共に「閉 $\rightarrow$ 閉」のときに比べて、 「開 $\rightarrow$ 閉」では L D系で $10 、$ 洋室系で $11 、 「 10 \rightarrow 10$ 」ではL D系で 15、洋室系で 17、「開 $\rightarrow$ 開」ではL D系で 31 、洋室系で 29 低下し た。

(2) 洋室系と L D 系を比較すると、 D数は、空開閉条件毎にみると、

\section{表2 空開閉条件別 D 数}

\begin{tabular}{|c|c|c|c|c|}
\hline 浿定經路 & 閉 $\rightarrow$ 閉 & 開 $\rightarrow$ 閉 & $10 \rightarrow 10$ & 開 \\
\hline LD系 & $\mathrm{D}-52$ & $\mathrm{D}-42$ & $\mathrm{D}-37$ & $\mathrm{D}-21$ \\
\hline 洋窒系 & $\mathrm{D}-46$ & $\mathrm{D}-35$ & $\mathrm{D}-29$ & $\mathrm{D}-17$ \\
\hline
\end{tabular}

D数は 測定点5点のエネルキ平圴面こよるもので、室間音圧レベル差関する遍音

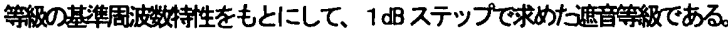

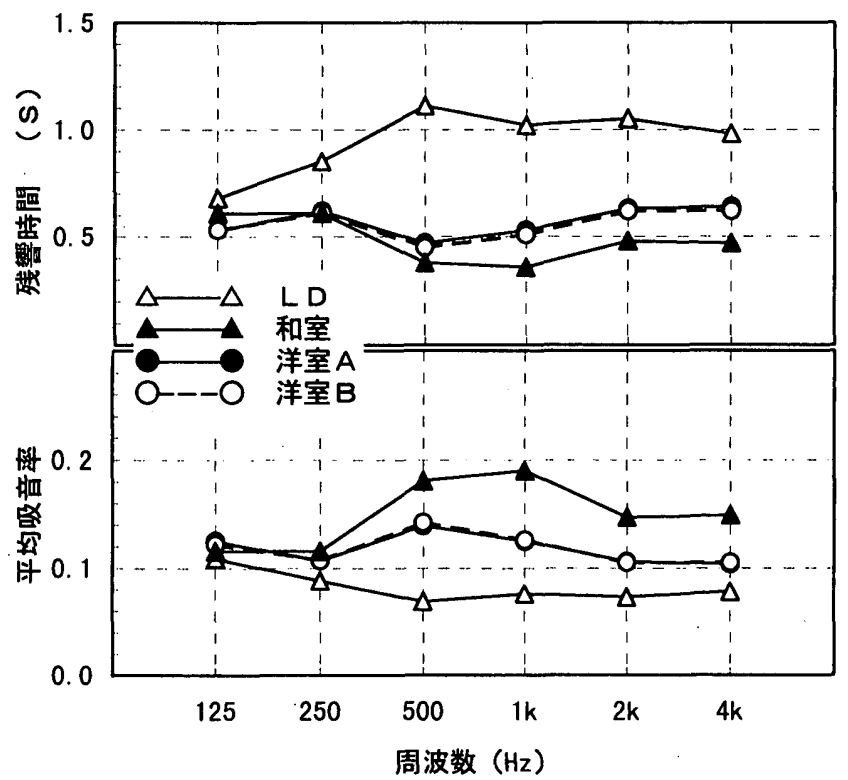

図 3 残響時間·平均吸音率
洋室系の方が小さい値を示した。これは、外廊下からの側路伝搬 が大きいこと（隣戸との境界のバルコニー隔板のような遮蔽物が 無い) などによるものと考えられる。

\section{2.3 残鲴時間・平均吸音率}

測定対象室各室の残響時間測定結果およびそれよりEyringの残 響式を用いて求めた平均吸音率を図 3 に示した。L D は、床仕上 げが木質仕上のため、和室、洋室よりも長い残響時間を示した。

\section{3. 主観評価実験}

\section{1 実験方法}

主観評価実験方法は前報と同様であるので、要点を次に示した。 主観評価実験システムを図 4 に示した。図中に示したインパル スレスポンスは、M系列ノイズを音源室内に放射し、受音室内の

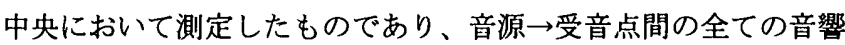
的情報を含んでいる。

このインパルスレスポンスとドライソース（実験用音声）を畳 込み実音化し、受聴点で被験者に呈示することにより、透過した 音声を受聴点で擬似的に聴取しているとの考え方をしている。た だし、実験は、音声用スピーカの数を 1 個として実施したもので あり、被験者は、音声の到来方向を向いているという想定をして いる。

主観評価実験に使用する音源用の音表は、「形容詞十名詞十動 詞」より成る脈略のない実験用文章とした。なお、1 音表は 50 文

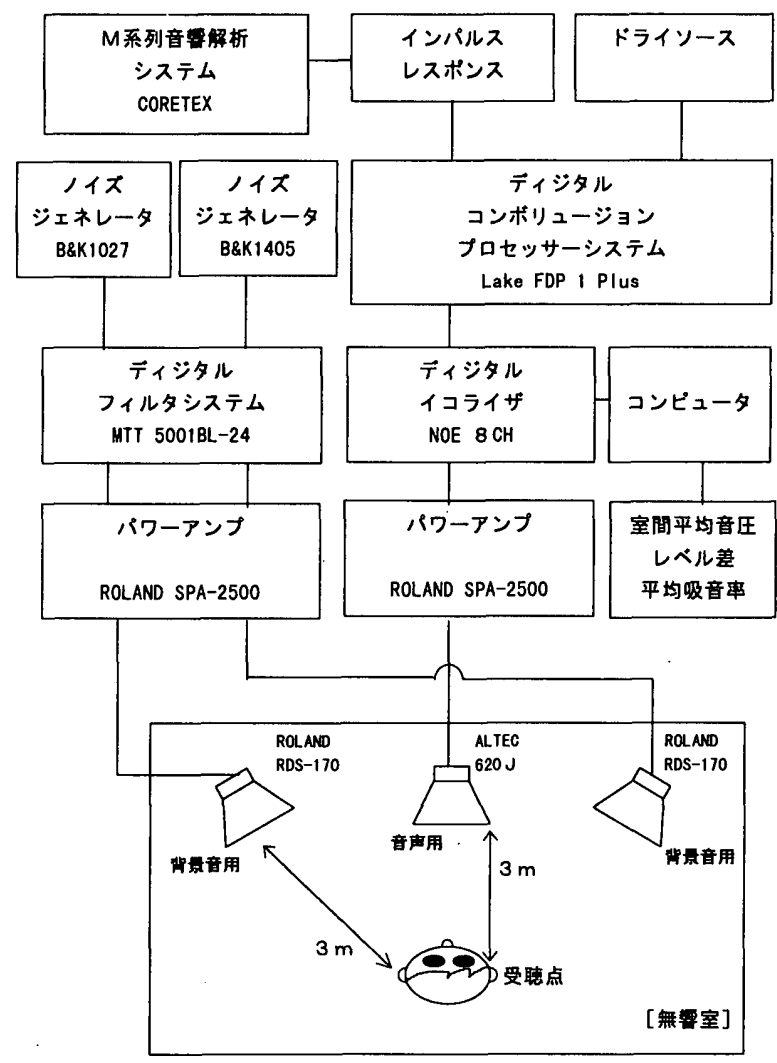

図 4 主観評価実験システム 
で構成されている。

これらの音表を使って、無響室において、フリーの女性アナウ ンサーによる実験用音声を作成した。さらに、各条件下で測定し たインパルスレスポンスに実験用音声をたたみ込み、主観評価実 験用音源とした。

主観評価実験は無響室で行い、聞こえ方のグレード」、「単語了 解度」を評価量とした測定を、前報の実験システムを用いて行っ た。

主観評価実験用の刺激音レベルの設定には、音源室における音 声のパワーレベル最大值を $79 \mathrm{~dB}$ ( $\mathrm{A}$ 特性音圧レベル、時間重み特 性 :FAST) とし、これが受音室に減衰して透過すると考え、透過音 のレベル（試験用音声のレベル）は、音源室、受音室共拡散音場 と仮定し、音声のパワーレベルから、図2 亿示した遮音特性と図 3 に示した平均吸音率などによって計算し設定した。この結果を 表 3 に示した。

透過音としての試験音は、試験条件毎に、受聴点において表 3 に示した設定值になるようにシステムをコンピュータ制御し、試 験用音声呈示スピーカより被験者に呈示した。なお、同一被験者 には全て異なる音表を使い、1 条件について 1 音表を呈示した。

負荷する背景音は、比較的静かな住宅地の定常的な環境騒音を 想定し、LD系、洋室系の両伝搬経路の受音䆓共、空開閉条件別 に 2 条件とし、それぞれの条件で同一レベルであるとした。すな わち、「空閉」の条件では、受音室内の $\mathrm{A}$ 特性音圧レベルを $25 \mathrm{~dB}$ 、 $30 \mathrm{~dB}$ の 2 条件とし、その周波数特性は、前報と同様にオクターブ $5 \sim 6 \mathrm{~dB}$ 下がりの特性に設定した。「空開」( $10 \mathrm{~cm}$ 開、全開)の条 件では、実測值から表 4 に示したように設定した。背景音は、背 景音呈示用スピーカ 2 個を用いて、無相関ノイズを試験用音声呈 示用スピーカの両側から被験者に呈示した。

試験音に対する被験者の回答は、聞こえ方のグレード」として、 意味がおかるわからないの判別には関係なく、「聞こえる（A）」、 「かすかに聞こえる（B)」、聞こえない（C)」の三者択一で被験 者に回答させた。

データの処理は、結果を条件毎に単一数值化するため、ここで は、それぞれの条件の回答結果に $\mathrm{A}: 1.0 、 \mathrm{~B}: 0.5 、 \mathrm{C}: 0$ の点数
表 3 試験用音声の周波数特性

$A: A$ 特性音圧レペル $(d B)$

\begin{tabular}{|c|c|c|c|c|c|c|c|c|}
\hline \multirow{2}{*}{ 位楼程路 } & \multirow{2}{*}{$\begin{array}{l}\text { 空開閉 } \\
\text { 条件 }\end{array}$} & \multicolumn{7}{|c|}{ 中心周波数 $\left(\mathrm{H}_{2}\right)$} \\
\hline & & 125 & 250 & 500 & $1 \mathrm{k}$ & $2 k$ & $4 k$ & A \\
\hline \multirow{4}{*}{ ம系 } & 閉一閉 & 18 & 34 & 24 & 13 & 6 & - & 27 \\
\hline & 開一閉 & 20 & 38 & 32 & 23 & 15 & 4 & 33 \\
\hline & $10 \rightarrow 10$ & 26 & 41 & 41 & 31 & 19 & 7 & 40 \\
\hline & 開一開 & 34 & 57 & 52 & 43 & 36 & 27 & 52 \\
\hline \multirow{4}{*}{ 洋室系 } & 閉一閉 & 23 & 39 & 29 & 19 & 11 & - & 32 \\
\hline & 開一閉 & 23 & 40 & 32 & 29 & 22 & 10 & 35 \\
\hline & $10 \rightarrow 10$ & 29 & 48 & 44 & 38 & 28 & 17 & 45 \\
\hline & 開一開 & 34 & 59 & 53 & 47 & 40 & 31 & 54 \\
\hline
\end{tabular}

表 4 試験用背景音の周波数特性

$\mathrm{A}: \mathrm{A}$ 特性音圧レペル $(\mathrm{dB})$

\begin{tabular}{|c|c|c|c|c|c|c|c|c|c|}
\hline \multirow{2}{*}{\multicolumn{2}{|c|}{$\begin{array}{l}\text { 受音室空 } \\
\text { 開閉条件 }\end{array}$}} & \multicolumn{8}{|c|}{ 中心周波数 (十) } \\
\hline & & 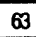 & 125 & 250 & 500 & $\mathbf{1 k}$ & $2 k$ & 4 & A \\
\hline 空 & \multirow{2}{*}{ 闌製 } & $\boldsymbol{3}$ & 33 & 27 & 22 & 17 & 12 & 6 & 5 \\
\hline 閉 & & 44 & 38 & 32 & 27 & 22 & 17 & 11 & 30 \\
\hline \multirow{4}{*}{ 開 } & \multirow{2}{*}{ 10 cm開 } & 47 & 41 & 37 & 32 & $\mathbf{2 6}$ & $D$ & 17 & 34 \\
\hline & & 52 & 46 & 42 & 37 & 31 & $\boldsymbol{b}$ & $\mathbf{2}$ & $\boldsymbol{B}$ \\
\hline & \multirow{2}{*}{ 全開 } & 53 & 40 & 44 & $\boldsymbol{3}$ & 34 & 27 & $\mathbf{2 0}$ & 41 \\
\hline & & 58 & 50 & 40 & 44 & $\boldsymbol{\circledast}$ & 32 & 31 & 46 \\
\hline
\end{tabular}

を与え、被験者が回答した点数の平均値を算出した（すなわち、0 〜 1.0 の範囲の值となる)。

「単語了解度」の場合には、脈略のない試験用文章の「名詞」の みを筆記回答させて、その正答率を算出した。

被験者は、正常な聴力を有する 20 代〜 50 代の男性 5 名、女性 3 名計 8 名である。

表 5 悹開閉条件別主観評価量

背覈音 (透過音)：A特性音圧レベル $(\mathrm{dB})$

\begin{tabular}{|c|c|c|c|c|c|c|c|c|c|}
\hline & \multicolumn{4}{|c|}{ 聞こえ方のグレード } & \multicolumn{4}{|c|}{ 単語了解度 （\%) } \\
\hline & & 閉 $\rightarrow$ 閉 & 開 $\rightarrow$ 閉 & $10 \rightarrow 10$ & 開 $\rightarrow$ 開 & 閉 $\rightarrow$ 閉 & 開 $\rightarrow$ 閉 & $10 \rightarrow 10$ & 開 $\rightarrow$ 開 \\
\hline \multirow{4}{*}{$\begin{array}{l}\mathrm{L} \\
\mathrm{D} \\
\text { 系 }\end{array}$} & 主観評価量 & 0.61 & 0.95 & 0.92 & 1.00 & 16 & 44 & 34 & 71 \\
\hline & 背景音(透過音) & $25(27)$ & $25(33)$ & $34(40)$ & $41(52)$ & $25(27)$ & $25(33)$ & $34(40)$ & $41(52)$ \\
\hline & 主観評価量 & 0.45 & 0.87 & 0.81 & 1.00 & 3 & 30 & 19 & 49 \\
\hline & 背景音(透過音) & $30(27)$ & $30(33)$ & $39(40)$ & $46(52)$ & $30(27)$ & $30(33)$ & $39(40)$ & $46(52)$ \\
\hline \multirow{4}{*}{$\begin{array}{l}\text { 洋 } \\
\text { 室 } \\
\text { 系 }\end{array}$} & 主観評価墨 & 0.83 & 1.00 & 1.00 & 1.00 & 29 & 56 & 52 & 68 \\
\hline & 背景音(透過音) & $25(32)$ & $25(35)$ & $34(45)$ & $41(54)$ & $25(32)$ & $25(35)$ & $34(45)$ & $41(54)$ \\
\hline & 主観評価量 & 0.71 & 0.94 & 0.93 & 1.00 & 11 & 40 & 37 & 48 \\
\hline & 背景音(透過音) & $30(32)$ & $30(35)$ & $39(45)$ & $46(54)$ & $30(32)$ & $30(35)$ & $39(45)$ & $46(54)$ \\
\hline
\end{tabular}




\section{2 主钼評価実験結果と考察}

\section{1) 闑こえ方のグレード}

空開閉条件別に、背景音レベルを 2 条件に変化させた場合の聞 こえ方のグレードを表 5 に示した。また、前報に示した「透過音 レベルと背景音レベルとの差」という物理量と聞こえ方のグレー ドとの関係を求めたものを図 5 に示した。

表 5 から次のことがいえる。

(1) L D 系の場合、音源室・受音室の空共に「閉，閉」のとき、背 景音レベル $30 \mathrm{~dB}$ の条件では、聞こえ方のグレードはほぼ 0.5 (「か すかに聞こえる」）を示し、その他の空開閉条件では、いずれも 0.5 を超える值を示した。また、背景音レベルが $25 \mathrm{~dB}$ の条件では、全 ての空開閉条件で 0.5 を超える値を示した。

(2) L D系と洋室系を比較すると、「開＼cjkstart開」(背景音レベルがいず れの場合でも 1.0 を示した）を除く各条件で、洋室系の方が聞こえ 方のグレードは大きい值を示した。これは、空開閉条件別に設定 した 2 条件の背景音は、L D系と洋室系で同一レベルであるとし たのに対し、洋室系の方が透過音レベルが大きいことによる。

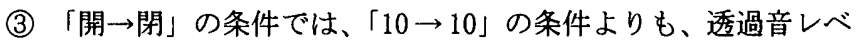
ルはL D系で $7 \mathrm{~dB}$ 、洋室系で $10 \mathrm{~dB}$ 小さいが、聞こえ方のグレード は、`LD系ではやや大きい值を示し、洋室系ではほぼ等しい值を 示した。これは、受音室の空が閉鎖されることによって背景音レ ベルも小さくなるので、透過音レベルの大小だけではなく、背景 音レベルとの相対的な関係で決まっているものと考える。

(4) 背景音レベルを $5 \mathrm{~dB}$ 上げると、いずれの背景音レベルでも 1.0 を示した「開 開」以外の条件では、聞こえ方のグレードは低下 した。

また、図 5 からは次のことがいえる。

(1)「開 $\rightarrow$ 閉」、「10 $\rightarrow 10 」$ 、「開 $\rightarrow$ 開」の条件と「閉 $\rightarrow$ 閉」の条件 を比較すると、聞こえ方のグレードは、やや「閉 $\rightarrow$ 閉」の条件の 方が小さ目の值を示した。

(2) 前報で得られた回帰直線と比較すると、聞こえ方のグレード

は、「透過音レベルと背景音レベルとの差」がー $3 \mathrm{~dB}$ 以上 $+6 \mathrm{~dB}$ 以下の範囲内では、前報の回帰直線 $\mathrm{A}$ に対し、 $\mathrm{A}-0.2$ の範囲内に ほぼ入る結果を得た。

\section{2) 単語了解度}

空開閉条件別に、背景音レベルを 2 条件に变化させた場合の単 語了解度を表 5 に、前報に示した、「透過音レベルと背景音レベル との差」という物理量と単語了解度との関係を図 6 に示した。

表 5 から次のことがいえる。

(1) 単語了解度が $5 \%$ 以下を示したのは、L D 系の場合で、音源室・ 受音室の空共に「閉 $\rightarrow$ 閉」のときで、背景音レベル $30 \mathrm{~dB}$ の条件だ けであった。

(2) L D系と洋室系を比較すると、「開 開」を除く各空開閉条件 で、洋室系の方が単語了解度は大きい值を示した。これは、1）で も述べたように、各条件別の背景音は、両伝搬経路で同一レベル としたのに対し、洋室系の方が透過音レベルが大きいことによる。

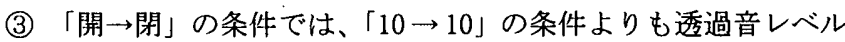
は小さいが、単語了解度は、L D 系ではほぼ10\%大きい值を示し、
洋窒系ではやや大きい值を示した。これは、1）でも述べたよう に、透過音レベルと背景音レベルとの相対的な関係で決まってい るからであると考える。

(4) 背景音レベルを $5 \mathrm{~dB}$ 上げると、全ての空開閉条件で単語了解 度は低下した。

また、図6から次のことがいえる。

(1)「開 $\rightarrow$ 開」の条件では、他の 3 つの条件と比較すると、単語了 解度は大き目の值を示した。

(2) 前報で得られた回帰直線と比較すると、単語了解度は、「閉 $\rightarrow$

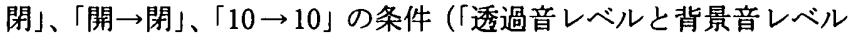
との差」がー $3 \mathrm{~dB}$ 以上 $+11 \mathrm{~dB}$ 以下) では、前報の回帰直線 B に対 し、 $\mathrm{B} \pm 10 \%$ 範囲内にほぼ入る結果を得た。

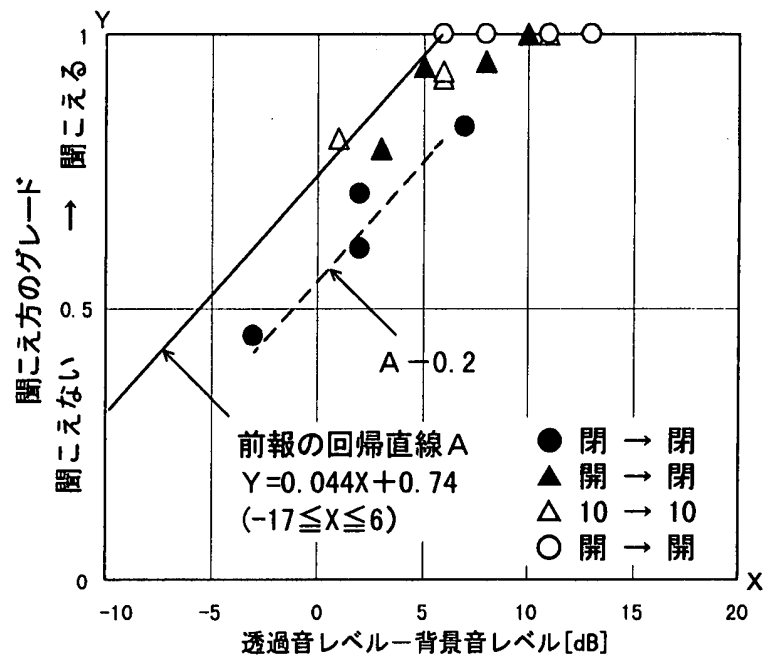

图 5 「透過音レベルと背景音レベルとの差」と 聞こえ方のグレード

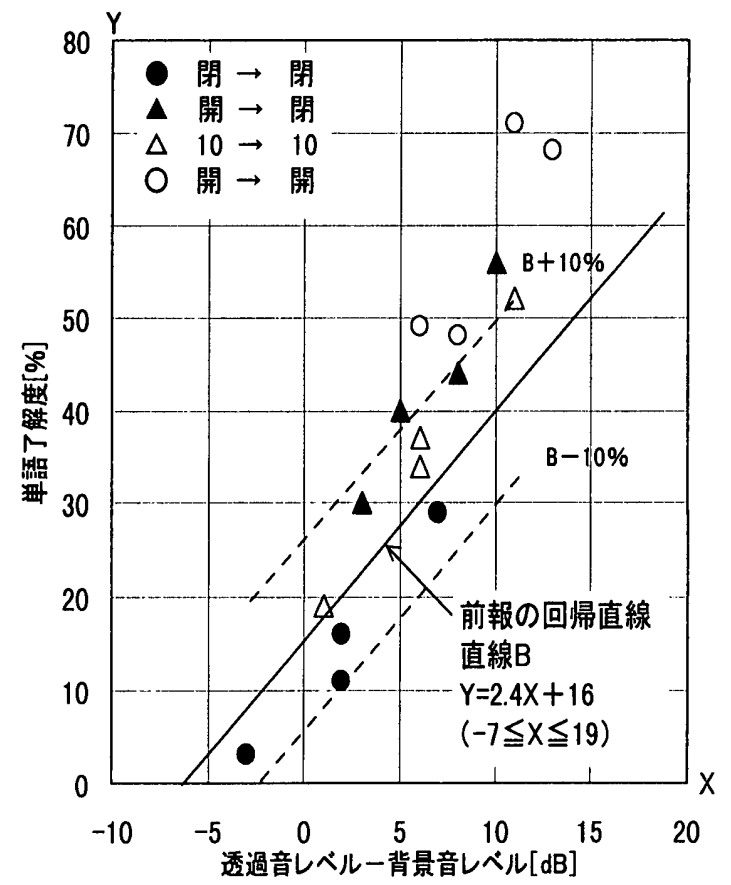

図6「透過音レベルと背景音レベルとの差」と単語了解度 


\section{4. 注と的}

本報では、「空開放」時の室間音圧レベル差の測定方法として、 室内平均音圧レベルの算出方法の検討を行ない、JIS法を適用して よいことを示したうえで、実際の集合住宅における基碳㥀料を基 に、空開開条件別に主䚇評価実験を行った結果、次のことがわかっ た。

(1) 洋室系（外廊下側の伝搬経路）とLD系（バルコニー側の伝搬 経路）を比皎すると、側路伝搬の影響が大きい洋室系の方が、透 過音レベルが大きく、闆こえ方のグレード、単語了解度共大きい 値を示した。

(2) 前報の結果と比皎すると、主稓評価量と「㤭過音レベルと背景 音レベルとの差」との関係でみると、閆こえ方のグレードに関し ては、前報の回帰直線より小さ目の值を示した。また、単語了解

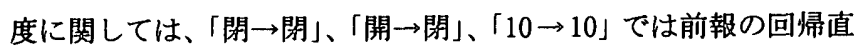
缐に近い傾向を示しているが、開 $\rightarrow$ 開」の条件では異なる傾向を 示し主㓋評価量は大きい值を示した。
今後、さらに空開䦥条件と遮音特性との関係、背景音の影響に ついてデータの集穦が必要である。特に入居者を祄象とした主稓 調至が重要であると考えている。また、空の開放時の単語了解度 が、前報の回帰直線より大きい値を示すことについて、透過音レ ベルとの関係なども含め、検討浬題として今後解明する必要があ ると考えている。

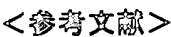

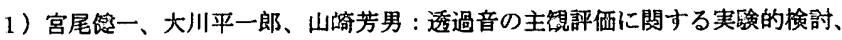
日本建筑学会計画系論文焦、No. 511、PP15 21，1998.9

2) 宫尾一、大川平一郎、山埼芳男 : 空開放条件が室間平均音圧レベル盖に

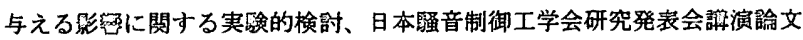
集 PP. 159 162, 1998. 9

3）宮尾一、大川平一郎、山埼芳男：透過音の評価に関寸る実驗的研究一第

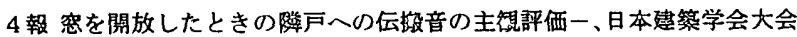

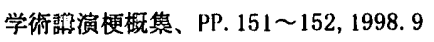

（1999年 5 月 27 日原稿受理，1999年11月 18 日採用決定） 